\title{
The SCC Reimagines Freedom of Association in 2015*
}

\author{
Ritu Khullar, QC and Vanessa Cosco ${ }^{\star \star}$
}

\section{Introduction}

The Supreme Court of Canada's recent jurisprudence on freedom of association is groundbreaking for labour lawyers and constitutional lawyers. It vindicates Chief Justice Dickson and precludes governments from lightly deciding to exclude certain workers from labour legislation or to prohibit them from collectively withdrawing their labour. The cases also have a broad range of implications.

After reviewing the evolution of the Court's approach to freedom of association (though excluding the Court's discussion of the corollary freedom not to associate), this paper reviews the Supreme Court of Canada's 2015 cases on freedom of association, also known as the 2015 Labour Trilogy, and discusses their implications: Mounted Police Association of Ontario $v$ Canada $(A G)^{1}$ addressing the right to join a union; Meredith $v$ Canada $(A G)^{2}$ addressing legislation overriding predetermined wage increases; and Saskatchewan Federation of Labour v Saskatchewan ${ }^{3}$ addressing the right to strike.

The paper then discusses how the 2015 Labour Trilogy reinvigorated the values underlying the Canadian Charter of Rights and Free$d_{0 m s}{ }^{4}$ and how it applies to strikes not directly relative to collective bargaining.

\section{The evaluation of the scope of Freedom of Association - The right to associate}

The Supreme Court of Canada first interpreted the right to freedom of association in Reference re: Public Service Employee Relations Act (Alberta). ${ }^{5}$ In that case, by way of a reference to the Alberta Court of Appeal, the Lieutenant-Governor in Council of Alberta asked the Courts whether provision of certain statutes prohibiting some workers from striking, and replacing strikes with compulsory interest arbitration, violated the Charter. A majority of the Supreme Court of Canada held there was no Charter violation and narrowly viewed the scope of the Charter-protected freedom as only encompassing an individual's right to,

- form an association;

- join an association;

- maintain an association;

- participate in an association's lawful activities; and

- do collectively what a person could do individually (the collective exercise of individual freedoms). 
Significantly, the Court held that the Charter did not protect the actions of the collective with respect to things it could only achieve collectively in the labour context: collectively bargain and strike. That is, no constitutional rights attached to the collective as a whole and the association could only exercise the lawful and constitution rights of its individual members. As a result, the decision precipitated a large body of literature on the Court's hostility to collective bargaining, the broken promise of the Charter for labour, and why labour would be wise to avoid the courts.

Dissenting in the Alberta Reference, Chief Justice Dickson gave section 2(d) a robust interpretation and found that it protects the activities of the collective group, including, in the labour context, collective bargaining and the collective withdrawal of labour, striking. ${ }^{6}$

Freedom of association in a labour context was back before the Supreme Court in 1999. In Delisle v Canada (Deputy $A G),{ }^{7}$ the Supreme Court considered whether provisions in federal labour legislation denying RCMP officers access to that labour regime violated the right to freedom of association protected by section $2(\mathrm{~d})$ of the Charter. In finding that there was no constitutional violation, the Court held that section 2(d) does not protect a right to form a particular type of association defined by statute or a right to access to a particular legislative framework within which to exercise freedom of association. Thus, the federal government was under no obligation to include the RCMP in federal labour legislation. This did not preclude them from organizing employee associations outside of the statutory scheme to collectively exercise their lawful rights.

Subsequently, in Dunmore v Ontario $(A G),{ }^{8}$ the Court started to chip away at the majority view in Alberta Reference, decided fourteen years earlier. In Dunmore, the Court considered whether the exclusion of agricultural workers from Ontario's Labour Relations Code violated the right to freedom of association guaranteed in section 2(d) of the Charter. The majority held that, while the Charter does not ordinarily oblige the state to take affirmative action to safeguard or facilitate the exercise of fundamental freedoms, there are circumstances in which there is such an obligation. Moreover, the Court held that the effective exercise of the right to freedom of association "may require not only the exercise in association of the constitutional rights and freedoms (such as freedom of assembly) and lawful rights of individuals, but the exercise of certain collective activities, such as making majority representations to one's employer."

Applying this test, the Court held that exceptional circumstances resulted in the exclusion of agricultural workers from Ontario's labour legislation violating the Charter. Specifically, the Court noted the following attributes of agricultural workers which precluded them from organizing absent legislative protection: political impotence; lack of resources to associate without state protection; vulnerability to reprisals by employers; poor pay; difficult working conditions; low levels of skill and education; low status; and limited employment mobility. ${ }^{10}$ Thus, the effect of the statutory exclusion was to prevent agricultural workers from organizing and thus the legislated exclusion infringed their freedom of association. The Court directed the Ontario government to enact legislation to give effect to agricultural workers' freedom of association.

In this way, the Court recognized the right of individuals to fulfill their potential through collective action that could not be accomplished individually. This recognition, that there are some things that can only be achieved through collective action, signaled a shift in the theoretical underpinnings of the Court's understanding of freedom of association. It contrasts with the majority's view in Alberta Reference that collective action is based on a group of individuals exercising their individual rights, and that no separate rights attach to the collective.

The Supreme Court further eroded the underpinnings of the Alberta Reference in Health Services and Support - Facilities Subsector Bargaining Association v British Columbia. ${ }^{11}$ At issue was the constitutionality of provincial legislation overriding certain key provisions of some public sector collective agreements, and precluding certain topics from being the subject of collective bargaining in the future. 
When first released, the Supreme Court's decision in Health Services was ground-breaking. For the first time, the Court held that the right to freedom of association protected by section 2(d) of the Charter encompasses the right to bargain collectively. Thus, employees have a right to unite, to present demands to employers collectively, and to engage in meaningful discussions in an attempt to achieve workplace-related goals. ${ }^{12}$ The Court explained that this constitutional right protects "the ability of workers to engage in associational activities, and their capacity to act in common to reach shared goals related to workplace issues and terms of employment."13

In Health Services, the Supreme Court held that, when considering whether there has been a Charter breach, Courts are to ask whether the effect of the state action substantially interferes with the activity of collective bargaining. As the Court explained: “...the state must not substantially interfere with the ability of a union to exert meaningful influence over working conditions through a process of collective bargaining conducted in accordance with the duty to bargain in good faith." ${ }^{14}$ The Court held that determining whether a government measure amounts to "substantial interference" involves two inquiries:

(a) An inquiry into the importance of the matter affected to the process of collective bargaining, specifically, to the capacity of the union members to come together and pursue collective goals in concert; and

(b) An inquiry into the manner in which the measure impacts on the collective right to good faith negotiation and consultation. ${ }^{15}$

Applying this test to the facts before it, the Court held that most of the legislation at issue did violate the right to freedom of association and was thus unconstitutional as it negated past collective agreements on important issues contracting out, layoffs, and bumping - and prohibited collective bargaining on these topics in the future. ${ }^{16}$

Following the Supreme Court's subsequent decision in Ontario $(A G) v$ Fraser, ${ }^{17}$ questions arose as to whether the Court was retreating from the more robust meaning it gave to freedom of association in Health Services.

At issue in Fraser was Ontario's Agricultural Employees Protection Act ${ }^{18}$ which the Ontario legislature enacted following the Supreme Court of Canada's decision in Dunmore. Rather than incorporating agricultural employees into Ontario's Labour Relations Act, ${ }^{19}$ the Ontario legislature passed the AEPA which establishes a separate labour regime for agricultural workers. The AEPA provides agricultural workers with:

1. the right to form or join an employees association;

2. the right to participate in the activities of an employees' association;

3. the right to assemble;

4. the right to make representations to their employers, through an employees association, respecting terms and conditions of employment; and

5. the right to protection against interference, coercion and discrimination in the exercise of that rights. ${ }^{20}$

Moreover, if an association of agricultural workers makes representations to their employer, either orally or in writing, the employer is required to listen to or read those representations. ${ }^{21}$ However, employers can still refuse to actually reach an agreement with the association. Moreover, the AEPA does not encompass the principle of majoritarian exclusivity reflected in Canadian labour legislation, does not provide a means for resolving bargaining impasses and interpreting collective agreements, and does not require employers to bargain in good faith. ${ }^{22}$

In upholding the $A E P A$, the Court made clear that section $2(\mathrm{~d})$ does not protect a particular model of collective bargaining or a particular outcome and does not require an employer to conclude a collective agreement with an employee association. ${ }^{23}$ That is, there will only be a breach of section 2(d) when, in the circumstances, "it is impossible to meaningfully exercise the right to associate." ${ }^{24}$ 
The Court concluded that the AEPA does not breach the section 2(d) right to freedom of association because it gives employee associations the right to make representations to their employers, and requires employers to listen to oral representations or read written representations, and thus contains an implicit duty on employers to consider employee representations in good faith and engage in meaningful dialogue. ${ }^{25}$

Thus, following Fraser essentially all that section 2 (d) protected is the freedom to associate in an attempt to achieve collective goals, and the right to have an association's collective representations considered and discussed in good faith, nothing more. ${ }^{26}$ Only laws or government inaction making it "impossible to achieve collective goals" or "impossible to meaningfully exercise the right to associate" violated freedom of association "by making it pointless." 27

In both Health Services and Fraser, the Court went to great pains to say that no outcome was guaranteed from the collective bargaining process as the Charter right only protected the process; and the Charter right did not give workers a right to a particular model of labour relations, such as the Wagner model enshrined in Canadian labour legislation.

\section{The 2015 cases}

With this background we get to the 2015 Labour Trilogy.

\section{A. The right to join an association: Mounted Police}

In Mounted Police, released January 16, 2015, the Court revisited Deslisle. ${ }^{28}$ In Mounted Police, two associations of RCMP officers challenged the constitutionality of provisions of the Public Service Labour Relations Act, ${ }^{29}$ and the Royal Canadian Mounted Police Regulations. ${ }^{30}$ The PSLRA establishes a labour relations and collective bargaining scheme for employees of the federal public service, but excludes members of the RCMP from that scheme. Instead, section 96 of the Regulation establishes the Staff Relations Representative Program, and it is through that pro- cess that RCMP members had to address labour issues with RCMP management. ${ }^{31}$ The program was carried out by individuals elected by RCMP members. Management consulted with the Program's representatives, but management was not obliged to bargain with the Program's representatives and all final decisions rested with management.

The two associations who brought the Charter challenge sought to represent their members in collective bargaining. The associations argued that their members were precluded from meaningfully exercising their freedom of association because their employer was not required to recognize them or to engage them in collective bargaining.

The Court explicitly adopted an expansive and purposive approach to interpreting freedom of association, drawing from Chief Justice Dickson's dissenting reasons in the Alberta Reference. Significantly, the Court recognized that freedom of association is more than just the right to join with others to form an association and the right to join with others the pursuit of constitutional rights. The Court concluded that a key purpose of section $2(\mathrm{~d})$ is to protect the ability of individuals to join with others to meet on more equal terms, the power and strength of other groups or entities, and then applied this to the labour relations context.

The Supreme Court held that the employee relations scheme, the Staff Relations Representative Program, was unconstitutional as it substantially interfered with meaningful collective bargaining because,

- it did not allow employees to choose the organization representing them and that organization was not accountable to RCMP members, and

- the scheme was part of management's organizational structure and the body representing the view of RCMP members was not independent from management.

Specifically in the labour relations context, the Court held that freedom of association includes employees' right to choose their bar- 
gaining agent and to be involved in establishing workplace goals, and the right to be independent from management so that the associations' goals are aligned with the goals and aspirations of its members. In other words, an aspect of meaningful collective bargaining is employees' ability to choose an organization that is independent from management to represent them, and to hold the organization accountable to the members. In reaching this conclusion, the Court made clear that that Parliament was not required to include RCMP members in the PSLRA.

\section{B. The right to bargain wages: Meredith}

On the same day that Mounted Police was released, January 16, 2015, the Court issued its second decision of 2015, Meredith. That case dealt with the constitutionality of the Expenditure Restraint $A c t^{32}$ introduced by the Government of Canada after the economic turmoil of 2008, to roll back already announced wage increases.

In Meredith members of the RCMP argued the Expenditure Restraint $A c t^{33}$ violated their freedom of association guaranteed by section 2(d) of the Charter by rolling back scheduled wage increases for RCMP members without prior consultation. The scheduled wage increases were not the result of collective bargaining. Rather, the Treasury Board establishes the pay and allowances paid to RCMP members. In doing so, the Treasury Board considers recommendations developed through the Pay Council which is an advisory board composed of representatives of RCMP management and RCMP members. The Act provided that any term or condition providing for additional increases during the period covered by the Act was of no effect. ${ }^{34}$

However, the Act contained the following exception with respect to RCMP members:

62. Despite sections 44 to 49 , the Treasury Board may change the amount or rate of any allowance, or make any new allowance, applicable to members of the Royal Canadian Mounted Police if the Treasury Board is of the opinion that the change or the new allowance, as the case may be, is critical to support transformation initiatives relating to the Royal Canadian Mounted Police. ${ }^{35}$
Because of this exception, the Act's effect on RCMP members differed from its effect on other members of the public service and the RCMP obtained an increase in compensation for offduty members required to be available for work and an increase in service pay.

In four cases, Courts of Appeal had held that the Expenditure Restraint Act did not violate section 2(d) of the Charter as it did not substantially interfere with freedom of association: Association of Justice Counsel $v$ Canada $(A G)^{36}$; Meredith $v$ Canada $(A G)^{37}$; Federal Government Dockyard Trades and Labour Council v Canada $(A G)^{38}$; Canada (Procureur général) c Syndicat canadien de la fonction publique, section locale $675 .^{39}$ These Courts held that section $2(\mathrm{~d})$ only protects the right to good faith exchanges and distinguished the legislation at issue in Health Services on the basis that the Expenditure Relief Act only overrode one element of collective agreements and only for a limited period of time. ${ }^{40}$

The Supreme Court held that the Expenditure Restraint Act did not violate section 2(d) because it did not introduce radical changes to significant terms of already concluded collective agreements. Rather, the Act capped wage increases consistent with the 'going rate' both inside and outside the public service. The fact that the limits were time-limited and confined only to wages were also significant factors, as was the fact that RCMP officers were still able to consult on compensation-related issues, a distinguishing feature of the case.

With respect to the other appellate cases addressing the Expenditure Restraint Act, the Supreme Court of Canada had denied leave to appeal in Association of Justice Counsel. ${ }^{41}$ While the affected unions had also sought leave to appeal in Federal Government Dockyard Trades and in Syndicat canadien de la function publique, instead of granting leave the Supreme Court remitted these cases back to the British Columbia and Quebec Courts of Appeal respectively, for reconsideration in light of the Supreme Court's decisions in Meredith and in Mounted Police. Those appellate Courts have yet to release their decision. 
The Meredith decision seems out of step with the other two cases in the 2015 Labour Trilogy: Mounted Police and the subsequently released SFL, discussed below. However, a distinguishing feature of the case is that the wages rates overridden by the Expenditure Restraint Act were not the result of free collective bargaining. For this reason, it will be interesting to see how the British Columbia and Quebec Courts of Appeal resolve their cases in light of Meredith. Importantly, when wage rates are the result of full collective bargaining, these are a key, fundamental term and condition of the resulting collective agreement and wages disputes are often the central issue in a strike or lockout. Wages are just as important to collective agreements, if not more important, than the collective agreement provisions regarding layoffs and bumping rights that were at issue in Health Services. ${ }^{42}$ Recall that in Health Services the Supreme Court of Canada found that it was unconstitutional for the British Columbia legislature to override those provisions of the collective agreement by legislation.

Moreover, collective bargaining is in part about the assumption of risk during bargaining. If wages trends and economic conditions improve after parties have reached their bargain, the employer may benefit from predetermined wage rates agreed to in not so favourable economic conditions, and conversely, if wage trends decline and economic conditions deteriorate, employees may benefit from wage rates negotiated in better times.

If the government as the employer can legislate rollbacks, it has undermined a key aspect of collective bargaining in that there is no risk to the employer if the negotiated rate of wage increases ends up being higher than economic conditions would perhaps dictate. Yet if the economy is expanding at a rate faster than the negotiated rate of wage increase, will the government legislate increases to wages? Likely not. Therefore, permitting the government to legislate its way out of collectively bargained contracts undermines collective bargaining and the parties' agreement.

Based on the Supreme Court's analytical framework as set out in other recent section 2(d) cases, one would expect the British Columbia and
Quebec Courts of Appeal to find that the government breached freedom of association by legislating rollbacks. The Courts would then consider whether those rollbacks were justified under section 1 . That is, the governments would have the onus of proving that the fiscal reality before it truly justified such rollbacks and the resulting infringement on freedom of association.

\section{The right to strike: $S F L$}

The Supreme Court of Canada issued the third case on January 30, 2015: Saskatchewan Federation of Labour. ${ }^{43}$ In that case, the constitutionality of two Saskatchewan statutes was at issue: The Public Service Essential Services Act $t^{44}$ and The Trade Union Amendment Act. ${ }^{45}$ The former statute had the effect of prohibiting public sector employees from striking. It did so by allowing public sector employers to designate virtually all of its employees "essential" and such a designated employee was prohibited from striking. The latter statute changed the union certification process by increasing the required level of written support and reducing the period for receiving written support from employers; the Court found it to be constitutional.

When the matter reached the Supreme Court of Canada, the Court held that the prohibition against Saskatchewan's public sector employees striking violated section 2(d) of the Charter and is not saved by section 1 . In coming to this conclusion, the Court revisited the purpose of the section 2(d) guarantee and adopted the dissenting reasons of Chief Justice Dickson in the Alberta Reference, decided eighteen years earlier.

In poetic reasons, the majority robustly interpreted freedom of association. Some examples of the language used include:

53 In Health Services, this Court recognized that the Charter values of "[h] uman dignity, equality, liberty, respect for the autonomy of the person and the enhancement of democracy" supported protecting the right to a meaningful process of collective bargaining within the scope of s. 2(d) (para. 81). And, most recently, drawing on these same values, in Mounted Police it confirmed that protection for a meaningful process of collective bargaining 
requires that employees have the ability to pursue their goals and that, at its core, s. 2(d) aims

to protect the individual from "stateenforced isolation in the pursuit of his or her ends"... . The guarantee functions to protect individuals against more powerful entities. By banding together in the pursuit of common goals, individuals are able to prevent more powerful entities from thwarting their legitimate goals and desires. In this way, the guarantee of freedom of association empowers vulnerable groups and helps them work to right imbalances in society. It protects marginalized groups and makes possible a more equal society. [para. 58]

54 The right to strike is essential to realizing these values and objectives through a collective bargaining process because it permits workers to withdraw their labour in concert when collective bargaining reaches an impasse. Through a strike, workers come together to participate directly in the process of determining their wages, working conditions and the rules that will govern their working lives (Fudge and Tucker, at p. 334). The ability to strike thereby allows workers, through collective action, to refuse to work under imposed terms and conditions. This collective action at the moment of impasse is an affirmation of the dignity and autonomy of employees in their working lives.

55 Striking - the "powerhouse" of collective bargaining - also promotes equality in the bargaining process: England, at p. 188. This Court has long recognized the deep inequalities that structure the relationship between employers and employees, and the vulnerability of employees in this context. In the Alberta Reference, Dickson C.J. observed that

[t]he role of association has always been vital as a means of protecting the essential needs and interests of working people. Throughout history, workers have associated to overcome their vulnerability as individuals to the strength of their employers. [p. 368]

And this Court affirmed in Mounted Police that
[Section] 2(d) functions to prevent individuals, who alone may be powerless, from being overwhelmed by more powerful entities, while also enhancing their strength through the exercise of collective power. Nowhere are these dual functions of s. 2(d) more pertinent than in labour relations. Individual employees typically lack the power to bargain and pursue workplace goals with their more powerful employers. Only by banding together in collective bargaining associations, thus strengthening their bargaining power with their employer, can they meaningfully pursue their workplace goals.

The right to a meaningful process of collective bargaining is therefore a necessary element of the right to collectively pursue workplace goals in a meaningful way... [the] process of collective bargaining will not be meaningful if it denies employees the power to pursue their goals.

(at paras. 70-71)

Judy Fudge and Eric Tucker point out that it is "the possibility of the strike which enables workers to negotiate with their employers on terms of approximate equality" (p. 333). Without it, "bargaining risks being inconsequential - a dead letter" (Prof. Michael Lynk, "Expert Opinion on Essential Services", at par. 20; A.R., vol. III, at p. 145).

56 In their dissent, my colleagues suggest that s. 2(d) should not protect strike activity as part of a right to a meaningful process of collective bargaining because "true workplace justice looks at the interests of all implicated parties" (para. 125), including employers. In essentially attributing equivalence between the power of employees and employers, this reasoning, with respect, turns labour relations on its head, and ignores the fundamental power imbalance which the entire history of modern labour legislation has been scrupulously devoted to rectifying. It drives us inevitably to Anatole France's aphoristic fallacy: "The law, in its majestic equality, forbids the rich as well as the poor to sleep under bridges, to beg in the streets, and to steal bread." ${ }^{46}$ 
The Court held that determining whether a legislative interference with the right to strike is unconstitutional requires consideration of whether it amounts to a substantial interference with collective bargaining. If so, such interference must survive section 1 scrutiny. In the case before it, the legislation did not survive such scrutiny because it allowed for "essential services" to be too broadly defined and did not provide for an alternative process for resolving collective bargaining impasse such as interest arbitration. Thus, following the Supreme Court's decision, it seems clear that a blanket prohibition on striking violates the Charter.

In coming to this conclusion, the Court explicitly confined its decision to strikes undertaken as part of collective bargaining and left for another day whether other types of collective work stoppages are also protected by section 2(d).

While the Court recognized that the right to strike is an integral part of collective bargaining, it also recognized that essential services legislation prohibiting the right to strike may be justified under certain circumstances. One question that remains then is what a constitutional restriction on the right to strike would that look like. Guidance may be found in Chief Justice Dickson's dissenting reasons in Alberta Reference where he found that, for the purpose of section 1 of the Charter, an essential service is one, "the interruption of which would threaten serious harm to the general public or to a part of the population. ${ }^{37} \mathrm{He}$ further found the International Labour Organization's definition of an "essential service" helpful: a service "whose interruption would endanger the life, personal safety or health of the whole or part of the population." ${ }^{48}$ Chief Justice Dickson also noted that having a fair and neutral third party dispute resolution process, like a fair compulsory interest arbitration process, may be an appropriate replacement for the right to strike in those circumstances.

SFL had an immediate and significant impact in Alberta. In 2013 the Alberta government had passed Bill 45, the Public Sector Services Continuation Act. ${ }^{49}$ Read together with the Labour Relations Code $^{50}$ the statute imposed severe penalties if employees employed in hospitals or health regions withdrew their labour for any reason. In challenging the new legislation, affected unions also challenged the blanket prohibition on striking in the Labour Relations Code that applied to the workers they represent. Following SFL, the litigation resolved with a consent judgment issued April 1, 2015 by the Alberta Court of Queen's Bench in which the Court declared those sections of the Labour Relations Code and similar sections of the Public Service Employee Relations Act unconstitutional, which declaration was suspended for 12 months to permit the government to bring in new legislation.

\section{Some Implications of the 2015 Labour Trilogy: Charter Values and Strikes for Non-Collective Bargaining Purposes}

While the 2015 Labour Trilogy is consistent with the Court's prior articulations of the values underlying the Charter, having done so in the context of collective rights re-animates these concepts that sometimes seem to languish on the pages of law reports.

\section{A. Autonomy, Self-Fulfillment and Dignity}

Mounted Police is significant in that it is consistent with the articulation of one of the underlying purposes of the Charter: to promote individual autonomy, self-fulfillment and dignity. ${ }^{51}$ It recognizes that the goals of autonomy, self-fulfillment and dignity can sometimes only be achieved by joining with others to meet on more equal terms the power and strength of other groups or entities. With respect to work generally, the Court reiterated its earlier observations that work provides an important avenue to autonomy and dignity for most individuals. ${ }^{52}$

With respect to SFL, preserving workers' freedom to withdraw their labour is also consistent with the values underlying the Charter. It violates people's personal autonomy, self-fulfillment and dignity, both individually and collectively, for the state to compel them to continue working against their will. The freedom to with- 
draw labour also helps redress the power imbalance between public sector employers backed by the state on the one hand, and employees on the other.

\section{B. Promotion of Democracy}

Preserving workers' freedom to bargain collectively and withdraw their labour also contributes to democratic discourse. This is because collective bargaining and withdrawals of labour aimed at achieving workplace goals themselves have social and political ramifications. Whether the issues in dispute are broad or narrow, the purpose and effect of a collective bargaining strike in particular is not limited to the particular dispute at hand. Unions have always been part of a broader social and political movement. By striking, employees are drawing the public's attention to social and political issues and "bring[ing] the debate on labour conditions into the public realm." 53 The conditions at issue may concern workplace safety, "the duration and location of work, parental leave, health benefits, or severance and retirement schemes." ${ }^{54}$ These are political and social issues. As Justice La Forest noted, unions "play a role in shaping the political, economic and social context within which particular collective agreements and labour relations disputes will be negotiated or resolved." ${ }^{55}$

Thus, a collective withdrawal of labour for collective bargaining purposes is about more than the conditions at the workplace; it has social and political ramifications and thus preservation of the freedom to withdraw labour contributes to the robustness of our democracy.

\section{Promotion of a More Fair Society}

What is unique about the Court's recent articulation of freedom of association is the adoption of Chief Justice Dickson's statement regarding the values underlying section $2(\mathrm{~d})$. In the Alberta Reference, Chief Justice Dickson stated in his dissent:

The purpose of the constitutional guarantee of freedom of association is, I believe, to recognize the profoundly social nature of human endeavours and to protect the individual from state-enforced isolation in the pursuit of his or her ends... . As social beings, our freedom to act with others is a primary condition of community life, human progress and civilized society. Through association, individuals have been able to participate in determining and controlling the immediate circumstances of their lives, and the rules, mores and principles which govern the communities in which they live... .

Freedom of association is most essential in those circumstances where the individual is liable to be prejudiced by the actions of some larger and more powerful entity, like the government or an employer. Association has always been the means through which political, cultural and racial minorities, religious groups and workers have sought to attain their purposes and fulfil their aspirations; it has enabled those who would otherwise be vulnerable and ineffective to meet on more equal terms the power and strength of those with whom their interests interact and, perhaps, conflict... .

What freedom of association seeks to protect is not association activities qua particular activities, but the freedom of individuals to interact with, support, and be supported by, their fellow humans in the varied activities in which they choose to engage. ${ }^{56}$

What has often been overlooked is that, in articulating the values underlying section 2(d), Chief Justice Dickson did not focus on the relationship between individuals and the state. Rather, he focused on the relationship between marginalized individuals and those who are more powerful. ${ }^{57}$

Likewise, in Mounted Police, after noting the above excerpt from Alberta Reference, the Court articulated the following with respect to the values underlying section $2(\mathrm{~d})$ :

58 This then is a fundamental purpose of $s$. 2(d) - to protect the individual from "stateenforced isolation in the pursuit of his or her ends": Alberta Reference, at p. 365. The guarantee functions to protect individuals against more powerful entities. By banding together in the pursuit of common goals, individuals are able to prevent more powerful entities from thwarting their legitimate goals and desires. In this way, the guarantee of 
freedom of association empowers vulnerable groups and helps them work to right imbalances in society. It protects marginalized groups and makes possible a more equal society.

66 In summary, s. 2(d), viewed purposively, protects three classes of activities: (1) the right to join with others and form associations; (2) the right to join with others in the pursuit of other constitutional rights; and (3) the right to join with others to meet on more equal terms the power and strength of other groups or entities.

70 [Section] 2(d) functions to prevent individuals, who alone may be powerless, from being overwhelmed by more powerful entities, while also enhancing their strength through the exercise of collective power. Nowhere are these dual functions of s. 2(d) more pertinent than in labour relations. Individual employees typically lack the power to bargain and pursue workplace goals with their more powerful employers. Only by banding together in collective bargaining associations, thus strengthening their bargaining power with their employer, can they meaningfully pursue their workplace goals.

71 The right to a meaningful process of collective bargaining is therefore a necessary element of the right to collectively pursue workplace goals in a meaningful way... [the] process of collective bargaining will not be meaningful if it denies employees the power to pursue their goals. ${ }^{58}$

In SFL, the Court again noted paragraphs 70 and 71 from Mounted Police and then commented:

Judy Fudge and Eric Tucker point out that it is "the possibility of the strike which enables workers to negotiate with their employers on terms of approximate equality" (p. 333). Without it, "bargaining risks being inconsequential - a dead letter" (Prof. Michael Lynk, "Expert Opinion on Essential Services", at par. 20; A.R., vol. III, at p. 145). ${ }^{59}$

\section{Strikes for Non-Collective Bargaining Purposes}

While the Mounted Police case contains broad language about the scope of freedom of association that could apply outside of the collective bargaining context, SFL is confined to strikes solely for the purpose of collective bargaining. It does not address withdrawals of labour for other than collective bargaining purposes such as for political protest. This is ironic because the definition of "strike" in the Saskatchewan legislation at issue prohibited employees from collectively withdrawing their labour for any purpose. ${ }^{60}$ Such broad definitions render employees' motive immaterial. ${ }^{61}$

While some provincial labour legislation defines a strike as a withdrawal of labour aimed at compelling an employer to accept terms or conditions of employment ${ }^{62}$ most statutory definitions are broad, like the Saskatchewan's legislation at issue in SFL. This broad definition of "strike" in contemporary legislation can be contrasted to the more narrow definition in Canada's original labour legislation. The Wartime Labour Relations Regulations defined a "strike" as a collective cessation of work done to compel an employer "to accept terms of employment." ${ }^{63}$

Recognition of the breadth of the prohibition in contemporary labour legislation is important because employees do withdraw their labour in a variety of circumstances, such as:

- to protest conscription and the shooting of a union organizer; ${ }^{64}$

- to protest a federal anti-inflation program; ${ }^{65}$

- to protest legislative initiatives regarding landlords and tenants, human rights, education, wage restraint and public sector employment; ${ }^{66}$

- to protest legislation removing matters from the collective bargaining system and giving the Government control over such things as class sizes, preparation time, length of the school year and designating non-teaching positions $;{ }^{67}$ and 
- to protest legislation interfering with their conditions of employment. ${ }^{68}$

While the reasoning in SFL is confined to strikes for collective bargaining purposes, in our view, the Charter protected freedom of association is engaged when workers collectively withdraw their labour for any purpose. That is, as with freedom of expression, the workers' motive when withdrawing their labour can be addressed under section 1 .

\section{Conclusion}

The Constitution is not a neutral legal instrument. All its parts, but especially the Charter, articulate the values that are central to Canada and to Canadians. The Charter not only identifies and defines rights and freedoms, it is an aspirational document. The 2015 Labour Trilogy breathed life into, not just freedom of association, but also the fundamental values underlying this aspirational document - autonomy, dignity, self-fulfillment, promotion of democracy and promotion of a more fair society. In doing so, it reminds us about the promise of the Charter, and that governments must tread carefully and precisely when curtailing fundamental freedoms.

\section{Endnotes}

12015 SCC 1, [2015] 1 SCR 3 [Mounted Police].

22015 SCC 2, [2015] 1 SCR 3 [Meredith].

32015 SCC 4, [2015] 1 SCR 245 [SFL].

4 Part I of the Constitution Act, 1982, being Schedule B to the Canada Act 1982 (UK), 1982, c 11 [Charter].

5 [1987] 1 SCR 313 [Alberta Reference].

6 Ibid.

7 [1999] 2 SCR 989.

82001 SCC 94, [2001] 3 SCR 1016.

9 Ibid at para 30.

10 Ibid at para 41.

112007 SCC 27, [2007] 2 SCR 391 [Health Services].

12 Ibid at para 89.

13 Ibid.

14 Health Services, supra note 11 at para 90, citing Dunmore, supra note 8 at para 16.

15 Ibid at paras 93-94.
16 Ibid.

172011 SCC 20, [2011] 2 SCR 3 [Fraser].

18 SO 2002, c 16 [AEPA]

19 SO 1995, c 1, Schedule A.

20 AEPA, supra note 18 s 1(2).

21 Fraser, supra note 17 at para 6.

22 Ibid at para 7.

23 Ibid at paras 41, 42, 46.

24 Ibid at para 47 [emphasis added].

25 Ibid.

26 Ibid at paras 2, 46.

27 Ibid at paras $46,47$.

28 Mounted Police, supra note 1.

29 SC 2003, c 22 [PSLRA].

30 SOR/88-361.

31 PSLRA, supra s 96.

32 SC 2009, c 2.

33 SC 2009, c 2.

34 Ibid ss 44-49.

35 Ibid s 62.

362012 ONCA 530, 117 OR (3d) 532, leave to appeal to SCCA refused, [2012] SCCA no 430 [Association of Justice Counsel].

372013 FCA 112.

382013 BCCA 371 [Dockyard Trades].

392014 QCCA 1068.

40 Association of Justice Counsel, supra note 35 at para 39; Dockyard Trades, supra note 37 at paras 52-54; Meredith, supra note 2 at para 96.

41 Supra note 36.

42 Supra note 11.

43 Supra note 3.

44 SS 2008, c P-42.2.

45 SS 2008, c 26.

46 Saskatchewan Federation of Labour, supra note 3 at paras 53-56.

47 Supra note 5 at para 106.

48 Ibid at para 71.

49 Bill 45, Public Sector Services Continuation Act. 1st Sess, 28th Leg, Alberta, 2013.

50 RSA 2000, c L-1.

51 Supra note 1.

52 See Alberta Reference, supra note 5 at p 386, Dickson CJ, dissenting; Wallace $v$ United Grain Growers Ltd, [1997] 3 SCR 701 at 741-42.

53 See RWDSU v Pepsi-Cola Canada Beverages (West) Ltd, [2002] 1 SCR 156 at 173-74 [Pepsi].

54 Ibid.

55 Lavigne v Ontario Public Service Employees Union, [1991] 2 SCR 211 at 334.

56 Alberta Reference, supra note 5 at 365-66.

57 Ibid.

58 Supra note 1 at paras 55-56, 70-71.

59 SFL, supra note 3 at para 55. 
60 The Public Service Essential Services Act, supra note 44 s 2(b)(k); The Trade Union Act, RSS 1978, c T-17, s 2(k.1).

61 See International Longshoremen's Association, Local 273 v Maritime Employers Association, [1979] 1 SCR 120 at 139.

62 See Labour Relations Code, supra note $50 \mathrm{~s}$ 1(v); The Labour Relations Act, RSM 1987, c L10, s 1.

63 PC 1003, s 2(1)(m).

64 SM Jamieson, Study No. 22: Times of Trouble: Labour Unrest and Industrial Conflict in Canada, 1900-66 (Ottawa: Minister of Supply and Services Canada, 1971) at 164-167.

65 British Columbia Hydro \& Power Authority and I.B.E.W. Local 258 and Local 213, [1976] 2 CLRBR 410 at 411; Re United Glass \& Ceramic Workers of North America et al and Domglas Ltd et al (1978), 19 OR (2d) 353 at 354 (HCJ Div Ct). This day of protest was a "strike" under Ontario's legislation but not under British Columbia's which, at the time, defined a strike as a withdrawal of labour related to terms and conditions of employment.

66 Health Labour Relations Association, [1983] BCLRBD no 220; Metro Transit Operating Co, [1983] BCLRBD no 219. Given British Columbia's legislation at the time, these protests were not "strikes".

67 Ontario (AG) v Ontario Teachers' Federation et al (1997), 36 OR (3d) 367 (Gen Div).

68 British Columbia Teachers' Federation $v$ British Columbia Public School Employers' Association, [2009] BCJ no 155 at paras 2, 5 (CA). This was considered a "strike" given that British Columbia's legislation was changed to no longer define a strike as a withdrawal of labour related to terms and conditions of employment. 